Pak. j. sci. ind. res. Ser. B: biol. sci. 201558 (3) 147-154

\title{
In-vitro Phytochemical and Antibacterial Activity of Abies cilicica subsp. cilicica
}

\author{
Basel Saleh* and Ayman Al-Mariri \\ Department of Molecular Biology and Biotechnology, Atomic Energy Commission of Syria, \\ P.O. Box 6091, Damascus, Syria
}

(received March 4, 2015; revised June 18, 2015; accepted July 27, 2015)

\begin{abstract}
Leaf and flowering cones methanolic, ethanolic and acetonic extracts of Abies cilicica subsp. cilicica plant were screened for phytochemical and inhibitory effect against 8 bacterial isolates. Qualitative phytochemical assay revealed that, flowering cones acetone extract exhibited the most of bioactive compounds compared to the leaf extracts with all examined solvents. Antibacterial activity of $A$. cilicica subsp. cilicica was determined by measuring the zone inhibition diameter (ZIs), activity index (A.I) and minimum inhibitory concentrations (MICs) against 8 bacteria (Staphylococcus aureus, Listeria monocytogenes, Bacillus cereus, Salmonella typhimurium, Escherichia coli: O157, Acinetobacter baumannii, Brucella abortus and Pseudomonas aeruginosa) isolates. Overall, acetonic flowering cones extracts were more potent against all tested isolates compared to the leaf ones. The lowest MICs value was recorded to be $0.42,0.52$ and $1.04 \mu \mathrm{g} / \mathrm{mL}$ for acetone, methanol and ethanol flowering cones, respectively, against the same pathogen A. baumannii. Based upon the current investigation, A. cilicica spp. cilicica could be considered as a potential endemic source against bacterial isolates.
\end{abstract}

Keywords: Abies cilicica, antibacterial activity, phytochemical assay, flowering cones

\section{Introduction}

Abies cilicica subsp. cilicica is an endemic subspecies to the mountains adjacent to the north-eastern Mediterranean coast. It occurs in Syria, Lebanon and Turkey. In Syria, it occurs at Slenfch (Lattakia) and forms mixed forests with Ostrya carpinifolia, Carpinus orientalis, Sorbus torminalis, Fraxinus ornus and Cerasus mahleb (Browicz, 1982). It is known as Cilician fir as an associated name. It is evident that this subspecies becomes one of the near threatened in the world. It worth noting that this subspecies is threatened in Syria and Lebanon (Knees and Gardner, 2013).

In Syria it grows in nature reserve located at $1500 \mathrm{~m}$ altitudes and occupies an area of 1350 hectares of a series of Syrian coastal mountains on eastern and western summit of the Prophet Mata (the highest peak in the Syrian coastal mountains $1562 \mathrm{~m}$ ). It has been declared natural reserve since 1996, but the start of its implementation was delayed until 2002. It has been protected by the financing of the Global Environment Facility.

A. cilicica (Ant. and Kotschy) subsp. cilicica (Cilician fir) belongs to the Pinaceae (Abietaceae) family. Abies genus involved 10 species and divided into 2 sub-species: subsp. cilicica (Buds not rosinous; young shoots hairy)

*Author for correspondence; E-mail: ascientific4@aec.org.sy and subsp. isaurica (Buds reinous; young shoots glabrous). A. cilicica subsp. cilicica is native to Mediterranean region of Turkey (Dayisoylu et al., 2009; Davis, 1967).

It has been demonstrated that, the essential oil cones A. cilicia subsp. cilicica has antimicrobial activity due to the effective compounds found, mainly, limonene, $\alpha$-pinene, $\beta$-pinene, and myrcene (Dayisoylu et al., 2009). Whereas, Alma et al. (2003) reported the antimicrobial activity of leaves essential oil of Syrian oreganum (Origanum syriacum L.). The later investigation revealed that, $\gamma$-terpinene, carvacrol, $p$-cymene and $\beta$-caryophyllene were the major compounds present in the $O$. syriacum L. leaf oil.

Recently, Patel et al. (2014) reported biological activity of $A$. pindrow leaves extracts and found that, leaf methanolic extract exhibited antioxidant effect due to presence of phenol and flavonoids. While, bronchoprotective activity was also attributed to the presence of terpenoids and flavonoids in leaf benze, acetone and ethanol extracts.

Few investigations focused on antibacterial and antifungal activities of Abies spp. extracts (Dayisoylu et al., 2009; Lee and Hong, 2009; Kizil et al., 2002; Diğrak et al., 1999; Bağci and Diğrak, 1997). Vishnoi 
et al. (2007) reported the antibacterial and antifungal activity of leaf of $A$. webbiana extract, while, Benli et al. (2008) described the antimicrobial activity of six endemic plant species from Turkey, A. nordmanniana subsp. bornmuelleriana is one of them. More recently, Patel et al. (2014) reported different pharmacological activities (anti-inflammatory, antioxidant, antiulcerogenic, antidiabetic and anxiolytic) activity of $A$. pindrow leaves extracts.

The study of biologically active compounds of plants has always been very interesting to researchers looking for novel sources of practical alternative against diseases (Alfatemi et al., 2015; Sharifi-Rad et al., 2015; 2014a; 2013), Pharmacological investigations in Abies spp. have been mainly focused on cones and resins essential oil activity. However, Abies spp. antibacterial inhibitory effect has not yet been examined in detail. Thereby, the current study was aimed to assess their potential use against different gram-positive and negative bacterial pathogens. A comparative assessment of its methanol, acetone and ethanol leaves and flowering cones extracts were studied.

\section{Materials and Methods}

Plant materials. Samples (leaf and flowering cones) were harvested from their natural habitats along the Syrian coastal mountains (Slenfch-Lattakia) at $1500 \mathrm{~m}$ altitudes with $1400 \mathrm{~mm}$ annual rainfall. Sampling was carried out in autumn $2013\left(35^{\circ} 3621 \mathrm{~N}\right.$ longitude and $36^{\circ} 1118$ E latitude) and fractions plants were shade dried for one week, powdered by special electric mill and stored separately in polyethylene bags until needed for analysis.

Microorganisms and growth conditions. The pure clinical isolates of Staphylococcus aureus, Listeria monocytogenes, Bacillus cereus, Salmonella typhimurium, Escherichia coli: O157, Acinetobacter baumannii, Brucella abortus and Pseudomonas aeruginosa were collected from the Microbiology and Immunology Division, Department of Molecular Biology and Biotechnology of Atomic Energy Commission of Syria (AECS) in Damascus-Syria. These bacteria present considerable interest in clinical laboratories.

The cultures were maintained at $37^{\circ} \mathrm{C}$ on $2 \mathrm{YT}$ agar (peptone, $16 \mathrm{~g} / \mathrm{L}$; yeast extract, $10 \mathrm{~g} / \mathrm{L} ; \mathrm{NaCl}, 5 \mathrm{~g} / \mathrm{L}$; agar, $13 \mathrm{~g} / \mathrm{L}$ [Difco, BD, Spars, MD]); and incubated for 24-48 h. Prior to antimicrobial sensitivity test, $0.2 \mathrm{~mL}$ of overnight culture of each organism was dispensed into $20 \mathrm{~mL}$ of sterile Mueller Hinton Broth (Hi-media Laboratory Pvt. Ltd., Mumbai, India) and then incubated for about $18-24 \mathrm{~h}$ to standardize the cultures to approximately $10^{6} \mathrm{CFU} / \mathrm{mL}$ (Al Mariri et al., 2013). The bacteria were suspended in a sterile phosphate-buffered saline (PBS). Bacterial abundance in PBS was monitored by recording the optical density (OD) at $590 \mathrm{~nm}$. The exact counts were assessed retrospectively by viable counts on $2 \mathrm{YT}$ agar plates.

Extraction of plant material. Crude extracts of $A$. cilicica leaf (LE) and flowering cones (FE) were phytochemicals screened using methanol, ethanol and acetone solvents as previously reported in many investigations (Gupta et al., 2011; Abdullahi et al., 2010; Rajesh et al., 2010).

For crude extracts preparation $500 \mathrm{~g}$ of shadedried pulverised plant material were subjected to extraction in a Soxhlet apparatus successively with solvent 10 times the volume of plant extract. The extraction was conducted until no more coloured matter was extracted. Solvent from each extracted mixture was evaporated to dryness using a rotary evaporator under reduced pressure at $40{ }^{\circ} \mathrm{C}$. All dried extracts were then kept in tightly fitting stopper bottles and stored in $4{ }^{\circ} \mathrm{C}$. The concentration of extract was considered $100 \mathrm{mg} / \mathrm{mL}$.

Phytochemical screening of extracts. Qualitative assay for the presence of secondary plant metabolites was carried out on the methanolic, ethanolic and acetonic leaf and flowering cones of $A$. cilicica for the presence of phytochemicals e.g. alkaloids, flavonoids, saponins, terpenoids, tannins and steroids compounds using the standard procedures previously described by SharifiRad et al. (2014b), Aida et al. (2001), Harborne (1991) and Trease and Evans (1989).

Determination of alkaloids content. The alkaloids content was determined as follows: $0.5 \mathrm{~g}$ of the sample was accurately weighed and defatted with $5 \%$ ethyl ether for $15 \mathrm{~min}$. The defatted sample was extracted for 20 min with $5.0 \mathrm{~mL}$ of $2 \mathrm{M} \mathrm{HCl}$ on a steam bath. The resulting mixture was centrifuged for $10 \mathrm{~min}$ at $3000 \mathrm{rpm}$ to remove supernatant. One $\mathrm{mL}$ of the filtrate was treated with a few drops of Mayer's reagent and a second $1.0 \mathrm{~mL}$ portion was treated similarly with Dragendorff's reagent. The observed coloured precipitates in the test tubes for either of these reagents, was taken as evidence for the presence of alkaloids.

Determination of flavonoids content. For flavonoids test, $1.0 \mathrm{~mL}$ of $10 \%$ lead acetate was added to $1.0 \mathrm{~mL}$ 
of the extract contained in a test tube. The formation of a yellow precipitate was taken as positive for flavonoids.

Determination of saponins content. The ability of saponins to produce frothing in aqueous solution was used as a screening test for the sample. $0.5 \mathrm{~g}$ of dried extract was shaken with water in a test tube, frothing (which persists on warming), was taken as evidence for the presence of saponins.

Determination of tannins content. For tannins test, $5.0 \mathrm{~g}$ of dried extract was stirred with $10.0 \mathrm{~mL}$ of distilled water. This was filtered and ferric chloride reagent (Ferric chloride hexahydrate: $7.50 \mathrm{~g}$, concentrated hydrochloric acid: $1.0 \mathrm{~mL}$, water to $100 \mathrm{~mL}$ ) was added to the filtrate. The formation of green precipitate was an indication of the presence of tannins.

Determination of steroids and terpenoids content. Chloroform extract $(0.5 \mathrm{~mL})$ of the dried extracts was evaporated to dryness on a water bath and heated with $3 \mathrm{~mL}$ of concentrated sulphuric acid for $10 \mathrm{~min}$ on a water bath, shaken well and allowed to stand. Appearance of red colour in the lower layer indicated the presence of steroids. Formation of reddish brown colour of interface after addition of concentrated sulphuric acid to the side carefully (without shaking) indicated the presence of terpenoids.

Antibacterial activity assay. The disc-diffusion assay. The disc-diffusion method was adopted to test the antibacterial activity as reported by earlier scientists (Derwich et al., 2010; Benli et al., 2008; Digrak et al., 1999). Ciprofloxacin was used as a standard drug to compare the results of experimental plant. Filter paper discs (Whatman No.1) of $6 \mathrm{~mm}$ diameter were prepared and sterilised. The discs impregnated with $100 \mu \mathrm{L}$ of extract dilutions $(100 \mathrm{mg} / \mathrm{mL})$ and reconstituted in minimum amount of methanol were applied over each of the culture plates previously seeded with the $10^{6}$ $\mathrm{CFU} / \mathrm{mL}$ cultures of bacteria. Bacterial cultures were then incubated at $37^{\circ} \mathrm{C}$ for $18 \mathrm{~h}$, while the paper discs impregnated with $20 \mu \mathrm{L}$ of a solution of $10 \mathrm{mg} / \mathrm{mL}$ of ciprofloxacin were used as standard antimicrobials for comparison. Negative control was prepared using methanol (final concentration of the solvent in the highest concentration of plant extract was tested). Antimicrobial activity was determined by measurement of zone of inhibition (in $\mathrm{mm}$ ) around each paper disc. For each extract, duplicate trials were conducted against each organism.
Activity index. Activity index (A.I) of A. cilicica subsp. cilicica plant extracts was calculated as previously reported by Gopalakrishnan et al. (2012) using the following formulae:

Activity index (A.I) = Inhibition zone of sample/ Inhibition zone of standard.

Commercial antibiotics ciprofloxacin $(100 \mathrm{mg} / \mathrm{mL})$ was used as standard for antibacterial activity.

Determination of minimum inhibitory concentrations (MICs). Microdilution broth susceptibility test was assessed according to Ríos-Dueñas et al. (2011). Three replicates of serial dilutions of extract $(50 \mathrm{mg} / \mathrm{mL})$ were prepared in LB broth medium in 96-well microtiter plates, using a range of concentrations for methanol and aqueous extracts of both A. cilicica leaf (LE) and flowering cones (FE) from 0.166 to $40 \mu \mathrm{L}$ per well. One hundred microlitres of freshly grown bacteria standardised $10^{6} \mathrm{CFU} / \mathrm{mL}$ in LB broth were added to each well. Positive control was achieved with the same conditions but without extract, negative control was also made with the same conditions but without adding the bacteria. The plate was incubated with shaking for $24 \mathrm{~h}$ at $37^{\circ} \mathrm{C}$. The lowest concentration that completely inhibited visual growth was recorded and interpreted as the MICs.

Statistical analysis. All statistical tests were performed in triplicates and values are presented as mean $\pm \mathrm{SD}$. Data analyses were evaluated by two-ways analysis of variance (ANOVA). All analyses were conducted with version 5.0 GraphPad Prism. P values of 0.05 or less were considered statistically significant.

\section{Results and Discussion}

Phytochemical analysis. Phytochemical test of LE and FE A. cilicica was studied in order to support their observed biological assay against tested bacteria isolates. Flavonoids and terpenoids were present in the three tested solvents (methanol, acetone and ethanol) (Table 1). While, tannins were presented in leaf extract in opposite manner to flowering cones. Saponins were present in leaf extract for the three examined solvents; whereas, they present only in acetone flowering cones and absent in methanol and ethanol of the same plant part (Table 1).

Bagci et al. (1999) investigated the essential oil composition of two shoots $A$. cilicica subsp. cilicica and isaurica in Turkey using GC-MS analysis. The later 
Table 1. Phytochemical test of leaf and flowering cones A. cilicica subsp. cilicica extracts

\begin{tabular}{|c|c|c|c|c|c|c|}
\hline \multirow{2}{*}{$\begin{array}{l}\text { Chemical } \\
\text { components }\end{array}$} & \multicolumn{3}{|c|}{ LE } & \multicolumn{3}{|c|}{ FE } \\
\hline & $\begin{array}{l}\text { Metha- } \\
\text { nol }\end{array}$ & $\begin{array}{l}\text { Ace- } \\
\text { tone }\end{array}$ & $\begin{array}{l}\text { Etha- } \\
\text { nol }\end{array}$ & $\begin{array}{l}\text { Metha- } \\
\text { nol }\end{array}$ & $\begin{array}{l}\text { Ace- } \\
\text { tone }\end{array}$ & $\begin{array}{l}\text { Etha- } \\
\text { nol }\end{array}$ \\
\hline Alkaloids & + & - & - & - & + & - \\
\hline Flavonoids & + & + & + & + & + & + \\
\hline Saponins & + & + & + & - & + & - \\
\hline Terpenoids & + & + & + & + & + & + \\
\hline Tannins & - & + & - & + & - & + \\
\hline Steroids & - & - & - & + & + & - \\
\hline
\end{tabular}

$\overline{\mathrm{LE}}=$ leaf extract; $\mathrm{FE}=$ flowering cones extract; $+=$ present; $-=$ absent

study revealed that oil of subsp. cilicica, was characterised by 57 compounds in which car-3-ene (14.2\%), caryophyllene oxide $(8.6 \%)$ and $\beta$-caryophyllene $(7.8 \%)$ were the major constituents. While, for subsp. isaurica, 23 compounds were characterised in their oil, where, $\beta$-pinene (29\%), $\alpha$-pinene (10\%), eremophilene $(9.3 \%)$ and $\beta$-caryophyllene $(8.8 \%)$ were the major compounds. Dönmez et al. (2012) and Kilic et al. (2010) reported that Abies species cones exhibited more phenolic compounds compared to other coniferous growing naturally in Turkey.

Phytochemical content and in-vitro antioxidant activities of $A$. pindrow LE dichloromethane, methanol and acetone extracts were investigated by Gupta et al. (2011). The study revealed that, acetone extract exhibited the highest total phenolic, flavonoid and flavonol content followed by methalonic then dichloromethane extract.

Recently, Uçar and Uçar (2014) reported the geographical distribution impact on the chemical compounds of needle oils of $A$. bornmuelleriana in Turkey using GC-MS/FID analysis. The later investigation revealed that $\alpha$-pinene and camphene $\%$ compounds among 38 chemicals compounds, increased in Turkey west-east direction.

Zone of inhibitions (ZIs) and activity index (A.I) assay. Susceptibility of examined bacteria isolates to LE and FE $A$. cilicica extracts has been presented in Table 2 . In this regards, ZIs values ranged between $14 \mathrm{~mm}$ with ethanol LE against $P$. aeruginosa and $24 \mathrm{~mm}$ with methanol FE against $S$. typhimurium isolate.

Table 2 shows that $S$. typhimurium was the most sensitive isolate with ZIs value of 20 and $24 \mathrm{~mm}$ with methanol LE and FE, 19 and $22 \mathrm{~mm}$ with ethanol LE and FE; while, it was recorded to be 20 and $23 \mathrm{~mm}$ with acetone LE and FE extracts, respectively. This observation suggests that, among the three tested solvents, acetone and methanol extracts were more potent than ethanol. Otherwise, FE extracts exhibited highest inhibitory effect against tested bacteria compared to the LE one.

Variance analysis showed that the effect of different extracts from the same plant parts using different solvents was significantly $(\mathrm{p}<0.05)$ different. In this respect, it was more significant $(\mathrm{p}<0.001)$ vs acetone for $B$. cereus; vs ethanol for $B$. abortus and also vs acetone for P. aeruginosa (Table 2). Moreover, our data revealed significant $(\mathrm{p}<0.05)$ differences regarding the effect of the same solvent using extracts from different plant parts. In this regards, these differences were more significant $(\mathrm{p}<0.001)$ vs $\mathrm{FE}$ for $S$. typhimurium and A. baumannii, vs FE for $A$. baumannii and also vs FE for L. monocytogeneses and A. baumannii (Table 2).

Previously, Bagci and Diðrak (1997) studied the antimicrobial effects of 4 fir essential oil against 12 microorganisms. The later study revealed that all extracts had antimicrobial activity against examined bacteria at different ratios. Moreover, not all tested extracts had inhibitory effect against $E$. coli, S. aureus and S. cerevisiae isolates.

Moreover, Digrak et al. (1999) reported the antimicrobial activity of 5 trees grown in Turkey. In the later study, chlorophorm, acetone and methanol (leaves, resins, bark, cones and fruits) were examined against 14 microorganisms. The later investigation showed that, the growth of $E$. coli was not affected by different plant parts extracts except by chlorophorm and acetone A. cilicica LE with ZIs of 16 and $18 \mathrm{~mm}$, respectively. While, Benli et al. (2008) reported that the ZIs value of LE A. nordmanniana extract was found to be $14 \mathrm{~mm}$ for $B$. subtilis RSHI pathogen.

Hemaiswarya et al. (2009) reported that, the mean ZIs of Ficus religiosa, Thespesia populnea and Hibiscus tiliaceus leaves aqueous, methanol and chloroform extracts against 9 microorganisms ranged between $10 \mathrm{~mm}$ (S. aureus) and $21 \mathrm{~mm}$ (P. aeruginosa and S. typhimurium). While, Derwich et al. (2010) reported the antibacterial activity of the leaves oil of Cedrus atlantica against 7 bacteria isolates. The later study revealed that E. coli, P. aeroginosa and S. aureus were the most sensitive tested pathogens as showed by the highest ZIs of 25, 21 and $22 \mathrm{~mm}$, respectively. Whereas, K. pneumoniae, S. intermedius and Enterococcus faecalis, were found to be more sensitive among bacteria with ZIs of 12, 19 and $11 \mathrm{~mm}$, respectively. While, 
moderate inhibitory effect was observed against Bacillus sphericus with ZIs of $6 \mathrm{~mm}$.

Table 2 shows that, the tested bacteria responded to A. cilicica extracts in different manner according to the examined plant fraction, tested solvent and bacteria isolate. In this regards, the highest ZIs value was recorded with methanol FE against $S$. typhimurium isolate (24 mm) (Table 2), whereas, the lowest ZIs one was pronounced with ethanol leaf against $P$. aeruginosa $(14 \mathrm{~mm})$.

Activity index (A.I) was also estimated and Table 3 shows that, ethanol LE exhibited the lowest A.I values against all tested isolates with A.I of 0.6 against
S. typhimurium, While, the highest antibacterial effect value was recorded for acetone and methanol FE with 1.2 against $P$. aeruginosa and $B$. abortus (Table 3 ). Similar finding (A.I = 1.2) was also observed in the case of methanol FE against B. abortus (Table 3).

From the data presented in Table 3, variance analyses showed that the effect of different extracts from the same plant parts using different solvents; and the effect of the same solvent using extracts from different plant parts, were significantly $(\mathrm{p}<0.05)$ different (Table 3$)$. Significant differences regarding A.I was followed the same tendency as for ZI.

Table 2. Antibacterial activity of the leaf and flowering cones A. cilicica subsp. cilicica extracts using disc-diffusion method

\begin{tabular}{|c|c|c|c|c|c|c|c|}
\hline \multirow[t]{3}{*}{ Microorganisms } & \multicolumn{5}{|c|}{ Zone of inhibition (mm) } & & \multirow[t]{3}{*}{ Control } \\
\hline & \multicolumn{2}{|l|}{ Methanol } & \multicolumn{2}{|c|}{ Ethanol } & \multicolumn{2}{|c|}{ Acetone } & \\
\hline & LE & $\mathrm{FE}$ & LE & $\mathrm{FE}$ & LE & $\mathrm{FE}$ & \\
\hline S. aureus & $17 \pm 0.09^{\mathrm{a}}$ & $20 \pm 0.25$ & $16 \pm 0.11^{\mathrm{c}}$ & $19 \pm 0.20$ & $18 \pm 0.2^{\mathrm{g}}$ & $21 \pm 0.17$ & $24 \pm 0.12$ \\
\hline L. monocytogeneses & $17 \pm 0.14$ & $19 \pm 0.14$ & $15 \pm 0.07$ & $17 \pm 0.12^{++++}$ & $16 \pm 0.15^{\mathrm{h}}$ & $20 \pm 0.14$ & $19 \pm 0.14$ \\
\hline B. cereus & $15 \pm 0.07^{* * *}$ & $17 \pm 0.1$ & $17 \pm 0.12^{*}$ & $18 \pm 0.13^{++++}$ & $19 \pm 0.17$ & $20 \pm 0.09$ & $21 \pm 0.12$ \\
\hline S. typhimurium & $20 \pm 0.22^{\mathrm{b}}$ & $24 \pm 0.26^{+}$ & $19 \pm 0.15^{\mathrm{d}}$ & $22 \pm 0.21$ & $20 \pm 0.14^{\mathrm{f}}$ & $23 \pm 0.16$ & $34 \pm 0.1$ \\
\hline E. coli $O: 157$ & $18 \pm 0.15^{* \mathrm{a}}$ & $21 \pm 0.17$ & $17 \pm 0.07^{* \mathrm{c}}$ & $19 \pm 0.15^{++++}$ & $19 \pm 0.15^{\mathrm{f}}$ & $22 \pm 0.21$ & $27 \pm 0.02$ \\
\hline A. baumannii & $19 \pm 0.08^{* * * * b}$ & $23 \pm 0.27^{++}$ & $16 \pm 0.14^{\mathrm{e}}$ & $20 \pm 0.17$ & $17 \pm 0.16^{\mathrm{h}}$ & $22 \pm 0.15$ & $25 \pm 0.18$ \\
\hline B. abortus & $17 \pm 0.16^{\mathrm{a}}$ & $20 \pm 0.14^{+++}$ & $15 \pm 0.16$ & $17 \pm 0.22^{++++}$ & $17 \pm 0.21^{\mathrm{f}}$ & $20 \pm 0.27$ & $17 \pm 0.2$ \\
\hline P. aeruginosa & $15 \pm 0.12^{* *}$ & $17 \pm 0.12$ & $14 \pm 0.09^{* *}$ & $15 \pm 0.17^{+++++}$ & $17 \pm 0.14$ & $19 \pm 0.23$ & $15 \pm 0.14$ \\
\hline
\end{tabular}

Table 3. Activity index (A.I) of the leaf and flowering cones A. cilicica sp. cilicica extracts

\begin{tabular}{|c|c|c|c|c|c|c|}
\hline \multirow[t]{3}{*}{ Microorganisms } & \multicolumn{6}{|c|}{ Activity index (A.I) } \\
\hline & \multicolumn{2}{|c|}{ Methanol } & \multicolumn{2}{|c|}{ Ethanol } & \multicolumn{2}{|c|}{ Acetone } \\
\hline & $\mathrm{LE}$ & $\mathrm{FE}$ & $\overline{\mathrm{LE}}$ & $\mathrm{FE}$ & $\overline{\mathrm{LE}}$ & $\mathrm{FE}$ \\
\hline S. aureus & $0.7 \pm 0.0^{\mathrm{a}}$ & $0.8 \pm 0.01$ & $0.7 \pm 0.00^{\mathrm{c}}$ & $0.8 \pm 0.01$ & $0.7 \pm 0.01^{\mathrm{g}}$ & $0.9 \pm 0.01$ \\
\hline L. monocytogeneses & $0.9 \pm 0.01$ & $1.0 \pm 0.01$ & $0.8 \pm 0.00$ & $0.9 \pm 0.01^{++++}$ & $0.8 \pm 0.01^{\mathrm{h}}$ & $1.0 \pm 0.01$ \\
\hline B. cereus & $0.7 \pm 0.00^{* * *}$ & $0.8 \pm 0.00$ & $0.8 \pm 0.01^{*}$ & $0.8 \pm 0.01^{++++}$ & $0.9 \pm 0.01$ & $0.9 \pm 0.00$ \\
\hline S. typhimurium & $0.6 \pm 0.01^{\mathrm{b}}$ & $0.7 \pm 0.01^{+}$ & $0.6 \pm 0.00^{\mathrm{d}}$ & $0.6 \pm 0.01$ & $0.6 \pm 0.00^{f}$ & $0.7 \pm 0.00$ \\
\hline E. coli $\mathrm{O}: 157$ & $0.7 \pm 0.01^{* a}$ & $0.8 \pm 0.01$ & $0.6 \pm 0.00^{* \mathrm{c}}$ & $0.7 \pm 0.01^{++++}$ & $0.7 \pm 0.01^{\mathrm{f}}$ & $0.8 \pm 0.01$ \\
\hline A. baumannii & $0.8 \pm 0.00^{* * * * b}$ & $0.9 \pm 0.01^{++}$ & $0.6 \pm 0.01^{\mathrm{e}}$ & $0.8 \pm 0.01$ & $0.7 \pm 0.01^{\mathrm{h}}$ & $0.9 \pm 0.01$ \\
\hline B. abortus & $1.0 \pm 0.01^{\mathrm{a}}$ & $1.2 \pm 0.01^{+++}$ & $0.9 \pm 0.01$ & $1.0 \pm 0.01^{++++}$ & $1.0 \pm 0.01^{\mathrm{f}}$ & $1.2 \pm 0.02$ \\
\hline P. aeruginosa & $1.0 \pm 0.01^{* *}$ & $1.1 \pm 0.01$ & $0.9 \pm 0.01^{* *}$ & $1.0 \pm 0.01^{+++++}$ & $1.1 \pm 0.01$ & $1.2 \pm 0.02$ \\
\hline
\end{tabular}

$\mathrm{LE}=$ leaf extract; $\mathrm{FE}=$ flowering cones extract.

(1) Comparing the effect of different extracts from the same plant parts using different solvents: ${ }^{*}=\mathrm{p}<0.05$ vs acetone for B. cereus and E. coli $\mathrm{O}: 157 ;{ }^{* *}=\mathrm{p}<0.01$ vs acetone for $P$. aeruginosa $;{ }^{* * *}=\mathrm{p}<0.001$ vs acetone for $B$. cereus; ${ }^{* * * *}=\mathrm{p}<0.01$ vs ethanol for $A$. baumannii $;{ }^{+}=\mathrm{p}<0.05 \mathrm{vs}$ ethanol for $S$. typhimurium; ${ }^{++}=\mathrm{p}<0.01$ vs ethanol for $A$. baumannii; ${ }^{+++}=\mathrm{p}<0.001$ vs ethanol for $B$. abortus; ${ }^{++++}=\mathrm{p}<0.01$ vs acetone for L. monocytogeneses, B. cereus, E. coli O:157 and B. abortus; ${ }^{+++++}=$ $\mathrm{p}<0.001$ vs acetone for $P$. aeruginosa.

(2) Comparing the effect of the same solvent using extracts against different plant parts: ${ }^{\mathrm{a}}=\mathrm{P}<0.01 \mathrm{vs}$ FE for $S$. aureus, E. coli $\mathrm{O}: 157$ and $B$. abortus $;{ }^{\mathrm{b}}=\mathrm{p}<0.001 \mathrm{vs} \mathrm{FE}$ for $S$. typhimurium and $A$. baumannii; ${ }^{\mathrm{c}}=\mathrm{p}<0.05$ vs $\mathrm{FE}$ for $S$. aureus and E. coli $\mathrm{O}: 157 ;{ }^{\mathrm{d}}=\mathrm{p}<0.01$ vs FE for $S$. typhimurium; ${ }^{\mathrm{e}}=\mathrm{p}<0.001$ vs FE for $A$. baumannii; ${ }^{\mathrm{f}}=\mathrm{p}<0.05$ vs FE for $E$. coli $\mathrm{O}: 157$, B. abortus and S. typhimurium; ${ }^{\mathrm{g}}=\mathrm{p}<0.01$ vs FE for $S$. aureus; ${ }^{\mathrm{h}}=\mathrm{p}<0.001$ vs FE for L. monocytogeneses and A. baumannii. 
Other investigation, however reported the antibacterial effect of essential oil extracts for A. holophylla and $A$. kornean. The later investigation indicated that $A$. kornean oil was more potent as antibacterial and antifungal properties than A. holophylla (Lee and Hong, 2009).

Minimum inhibitory concentrations (MICs) test. Susceptibility and MICs was investigated against 8 bacterial isolates using standard antibiotics ciprofloxacin $(100 \mathrm{mg} / \mathrm{L})$ as a reference.

The tube dilution method was applied to determinate the MICs. Calculated MICs values were illustrated in Table 4. MICs was determined; these values were varied mainly according to the plant part (Table 4). It was worth noting that, the best MICs value was recorded to be 0.42 and $0.52 \mu \mathrm{g} / \mathrm{mL}$ for acetone and methanol FE against $A$. baumannii followed by $E$. coli $\mathrm{O}: 157(0.63$ $\mu \mathrm{g} / \mathrm{mL})$ and $S$. typhimurium $(0.83 \mu \mathrm{g} / \mathrm{mL})$ with $\mathrm{FE}$ acetone extract (Table 4).

Our results showed no significant differences regarding the effect of different extracts from the same plant parts using different solvents, and the effect of the same solvent using extracts from different plant parts on MICs; except $\mathrm{P}<0.05$ vs FE for L. monocytogeneses (Table 4).

Phytochemical test revealed the presence of steroids and alkaloids in acetonic FE and their absence in the other extracts, could explain the difference in their biological activity. These chemical components differ in their solubility degree according to examined solvent. These secondary metabolites have been successfully identified in plant extracts and investigated on its antimicrobial inhibitory against some bacterial pathogens
(Gupta et al., 2011; Adeshina et al., 2010; Ebana et al., 1991). These compounds had different inhibitory mechanisms against microorganisms and acted in different manners. Thereby, the synergic effect of all bioactive compounds presented in FE acetonic makes it as the most potent extract among the different examined crude extracts.

Dayisoylu et al. (2009) reported the antimicrobial effect of A. cilicica. The later study mentioned that, the highest MICs value $(3.5 \mu \mathrm{g} / \mathrm{mL})$ was determined against $P$. aeruginosa and $K$. pneumonia. Our observation was in accordance of the previous finding, where MICs value was found to be 3.33 and $4.17 \mu \mathrm{g} / \mathrm{mL}$ for methanol FE and LE, respectively, against $P$. aeruginosa.

Lee and Hong (2009) reported the antibacterial effect of essential oil extracts for A. holophylla and A. kornean. The previous study showed the great inhibitory effect extracts against different tested bacteria in range of 2.2-8.8 $\mu \mathrm{g} /$ disc by the agar disc-diffusion methods with MICs value of $5.5-21.8 \mathrm{mg} / \mathrm{mL}$ by the microdilution methods.

Previously, Vishnoi et al. (2007) reported that, the methanol LE of different species of Abies spp. exhibited wide spectrum antimicrobial activity. While, Benli et al. (2008) reported the antimicrobial activity of A. nordmanniana subsp. bornmuelleriana endemic plant species from Turkey. The later investigation revealed that, the MICs of LE A. nordmanniana extract was 314 $\mathrm{mg} / \mathrm{mL}$ against $B$. subtilis with minimum bacteriocidal concentration (MBC) value of $4.91 \mathrm{mg} / \mathrm{mL}$.

Lee and Hong (2009) reported the antibacterial effect of essential oil extracts for A. holophylla and A. kornean.

Table 4. Minimum inhibition concentrations (MICs) values of the leaf and flowering cones A. cilicica sp. cilicica extracts against the pathogenic bacterial isolates

\begin{tabular}{|c|c|c|c|c|c|c|}
\hline \multirow[t]{3}{*}{ Microorganisms } & \multicolumn{5}{|c|}{ Minimum inhibition concentrations (MICs) $(\mu \mathrm{g} / \mathrm{mL})$} & \\
\hline & \multicolumn{2}{|c|}{ Methanol } & \multicolumn{2}{|c|}{ Ethanol } & \multicolumn{2}{|c|}{ Acetone } \\
\hline & LE & $\mathrm{FE}$ & LE & $\mathrm{FE}$ & LE & $\mathrm{FE}$ \\
\hline S. aureus & $6.67 \pm 2.89$ & $4.17 \pm 1.44$ & $8.33 \pm 2.89$ & $5.00 \pm 0.00$ & $5.83 \pm 3.82$ & $3.33 \pm 1.44$ \\
\hline L. monocytogeneses & $6.67 \pm 2.89$ & $3.33 \pm 1.44$ & $8.33 \pm 2.89$ & $5.00 \pm 0.00$ & $8.33 \pm 2.89^{*}$ & $3.33 \pm 1.44$ \\
\hline B. cereus & $8.33 \pm 2.89$ & $3.33 \pm 1.44$ & $6.67 \pm 2.89$ & $3.33 \pm 1.44$ & $6.67 \pm 2.89$ & $3.33 \pm 1.44$ \\
\hline S. typhimurium & $2.92 \pm 1.91$ & $1.04 \pm 0.36$ & $2.08 \pm 0.72$ & $1.45 \pm 0.96$ & $1.67 \pm 0.72$ & $0.83 \pm 0.36$ \\
\hline E. coli $\mathrm{O}: 157$ & $2.92 \pm 1.91$ & $0.83 \pm 0.36$ & $3.33 \pm 1.44$ & $1.04 \pm 0.36$ & $2.08 \pm 0.72$ & $0.63 \pm 0.00$ \\
\hline A. baumannii & $2.08 \pm 0.72$ & $0.52 \pm 0.18$ & $2.92 \pm 1.91$ & $1.04 \pm 0.36$ & $2.08 \pm 0.72$ & $0.42 \pm 0.18$ \\
\hline B. abortus & $2.08 \pm 0.72$ & $1.67 \pm 0.72$ & $2.5 \pm 0.00$ & $2.08 \pm 0.72$ & $2.92 \pm 1.91$ & $1.04 \pm 0.36$ \\
\hline P. aeruginosa & $4.17 \pm 1.44$ & $3.33 \pm 1.44$ & $5.83 \pm 3.82$ & $6.67 \pm 2.89$ & $4.17 \pm 1.44$ & $4.17 \pm 1.44$ \\
\hline
\end{tabular}

$\mathrm{LE}=$ leaf extract $\mathrm{FE}=$ flowering cones extract; ${ }^{*}=\mathrm{p}<0.05$ vs FE for L. monocytogeneses. 
The later investigation revealed that Abies extracts oils was highly potent against bacteria with MICs value of $5.5-21.8 \mathrm{mg} / \mathrm{mL}$ using the microdilution methods. Whereas, Derwich et al. (2010) investigated inhibitory effect of the leaves oil of $C$. atlantica against 7 bacteria pathogens. The previous study showed that, this extract was active against $E$. coli, $P$. aeroginosa, $S$. aureus and $S$. intermedius with MICs value of $0.25,0.980 .68$ $\mathrm{mg} / \mathrm{mL}$ and $1.25 \mathrm{mg} / \mathrm{mL}$, respectively. While, it exhibited more potent activity against $K$. pneumoniae, E. faecalis and $B$. sphericus with MICs value of $1.45,1.31$ and $1.62 \mathrm{mg} / \mathrm{mL}$, respectively.

Recently, Patel et al. (2014) described the biological activity of $A$. pindrow LE. They reported that ethanol LE exhibited anti-inflammatory, antidiabetic and anxiolytic activity, antioxidant effect with LE methanolic extract while, antiulcerogenic activity was detected with petroleum ether, benzene and chloroform extracts.

\section{Conclusion}

Phytochemical test and inhibitory effect of the crude ethanol, methanol and acetone of LE and FE of $A$. cilicica subsp. cilicica were evaluated against 8 bacteria isolates. It was noticed that, FE acetone extract exhibited the most of bioactive compounds compared to the LE with all examined solvents. It is worth noting that the A. cilicica antibacterial activity against both gram positive and negative bacteria was in the order of acetone $<$ methanol $<$ ethanol. Overall, FE were more potent against all tested isolates compared to the LE ones. On the other hands, ethanol extract had the lowest antibacterial activity by showing the smallest ZIs values. Overall, $A$. baumannii isolate could be considered as the most sensitive pathogen to $A$. cilicica extracts by showing the lowest MICs values of $0.42,0.52$ and $1.04 \mu \mathrm{g} / \mathrm{mL}$ for acetone, methanol and ethanol FE, respectively.

\section{Acknowledgement}

We thank I. Othman (Director General of AECS) and N. Mir Ali (Head of Molecular Biology and Biotechnology Department in AECS) for their support, and also the Plant Biotechnology Group for technical assistance. Indeed, thanks to Mr. M. Safi for his help in statistical analysis performance.

\section{References}

Abdullahi, M.I., Iliya, I., Haruna, A.K., Sule, M.I., Musa, A., Abdullahi, M.S. 2010. Preliminary phytochemical and antimicrobial investigations of leaf extracts of Ochna schweinfurthiana (Ochnaceae). African Journal of Pharmacy and Pharmacology,
4: 83-86.

Adeshina, G.O., Okeke, C.E., Osuagwu, N.O., Ehinmidu, J.O. 2010. Preliminary in-vitro antibacterial activities of ethanolic extracts of Ficus sycomorus Linn. and Ficus platyphylla Del. (Moraceae). African Journal of Microbiology Research, 4: 598-601.

Aida, P., Rosa, V., Blamea, F., Tomas, A., Salvador, C. 2001. Paraguyan plants used in traditional medicine. Journal of Ethno-pharmacology, 16: 93-98.

Alfatemi, S.M.H., Sharifi-Rad, J.S., Sharifi-Rad, M., Mohsenzadeh, S., Teixeira da Silva, J.A. 2015. Chemical composition, antioxidant activity and in vitro antibacterial activity of Achillea wilhelmsii C. Koch essential oil on methicillin-susceptible and methicillin-resistant Staphylococcus aureus spp. 3 Biotech, 5: 39-44.

Alma, M.H., Mavi, A., Yildirim, A., Digrak, M., Hirata, T. 2003. Screening chemical composition and in-vitro antioxidant and antimicrobial activities of the essential oils from Origanum syriacum growing in Turkey. Biological and Pharmaceutical Bulletin, 26: $1725-1729$.

Al-Mariri, A., Swied, G., Oda, A., Al-Hallab, L. 2013. Antibacterial activity of Thymus syriacus Boiss essential oil and its components against some Syrian gram-negative bacteria isolates. Iranian Journal of Medical Sciences, 38: 180-186.

Bagci, E., Baser, K.H.C., Kürkçüoðlu, M., Babaç, T., Çelik, S. 1999. Study of the essential oil composition of two subspecies of Abies cilicica (Ant. et Kotschy) Carr. from Turkey. Flavour and Fragrance Journal, 14: 47-49.

Bagci, E., Diðrak, M. 1997. In-vitro antimicrobial activities of some fir essential oils. Turkish Journal of Biology, 21: 273-281.

Benli, M., Bingo, U., Geven, F., Guney, K., Yigit, N. 2008. An investigation on the antimicrobial activity of some endemic plant species from Turkey. African Journal of Biotechnology, 7: 1-5.

Browicz, K. 1982. Chorology of Trees and Shrubs in South-West Asia and Adjacent Regions. vol. 1, pp. 172, Polish Scientific Publishers, Warsawa, Poland.

Davis, P.H. (ed.), 1967. Flora of Turkey and the East Aegean Islands, vol. 9, 87 pp., Edinburg University Press, Edinburg, UK.

Dayisoylu, K.S., Duman, A.D., Alma, M.H., Digrak, M. 2009. Antimicrobial activity of the essential oils of rosin from cones of Abies cilicica subsp. cilicica. African Journal of Biotechnology, 8: 50215024.

Derwich, E., Benziane Z., Boukir, A. 2010. Chemical composition and In-vitro antibacterial activity of 
the essential oil of Cedrus atlantica. International Journal of Agriculture and Biology, 12: 381-385.

Digrak, M., Alma, M.H., Ilcim, A. 1999. Antibacterial and antifungal effects of various commercial plant extracts. Pharmaceutical Biology, 37: 216-220.

Dönmez, I.E., Hafizoðlu, H., Kilic, A., Tümen, I., Sivrikaya, H. 2012. Chemical composition of fourteen different coniferous species cones growing naturally in Turkey. Wood Research, 57: 339-344.

Ebana, R.U.B., Madunagu, B.E., Ekpe, E.D., Otung, I.N. 1991. Microbiological exploitation of cardiac glycosides and alkaloids from Garcinia kola, Borreria ocymoides, Kola nitida and Citrus aurantifoli. Journal of Applied Bacteriology, 71: 398-401.

Gopalakrishnan, S., Kalaiarasi, T., Rajameena, R. 2012. Evaluation of antibacterial activity of the fruits of Cucumis trigonus Roxb. International Research Journal of Pharmacy, 3: 256-258.

Gupta, D., Bhardwaj, R., Gupta, R.K. 2011. In-vitro antioxidant activity of extracts from the leaves of Abies pindrow Royle. African Journal of Traditional, Complementary and Alternative Medicines, 8: 391397.

Harborne, J.B. 1991. Recent advances in the ecological chemistry of plant terpenoids. In: Ecological Chemistry and Biochemistry of Plant Terpenoids, J.B. Harborne and F.A. Tomas-Barberan (eds.), pp. 399-426, Clarendon Press, Oxford, UK.

Hemaiswarya, S., Poonkothai, M., Raja, R., Anbazhagan, C. 2009. Comparative study on the antimicrobial activities of three Indian medicinal plants. Egyptian Journal of Biology, 11: 52-57.

Kilic, A., Hafizoglu, H., Tümen, I., Dönmez, I.E., Sivrikaya, H., Hemming, J. 2010. Phenolic extractives of cones and berries from Turkish coniferous species. European Journal of Wood and Wood Products, 69: 63-66.

Kizil, M., Kizil, G., Yavuz, M., Aytekin, C. 2002. Antimicrobial activity of rosins obtained from the roots and stems of Cedrus libani and Abies cilicica. Applied Biochemistry and Microbiology, 38: 144146.

Knees, S.G., Gardner, M.F. 2013. Abies cilicica subsp. cilicica, from the website, Threatened Conifers of The World (http://threatenedconifers.rbge.org.uk/ taxa/details/95). Downloaded on 19 November 2013.

Lee, J.H., Hong, S.K. 2009. Comparative analysis of chemical compositions and antimicrobial activities of essential oils from Abies holophylla and Abies koreana. Journal of Microbiology and Biotech- nology, 19: 372-377.

Patel, K., Kumar, V., Singh, P.K., Kumar, V. 2014. Phytochemistry and pharmacology of Abies pindrow (Royle ex D. Don) Royle: A Review. Pharmagene Journal, 2: 36-39.

Rajesh, K., Harshaw, R., Ahmed, M.G., Hareesh, A.R., Thammanna, G.S.S., Dinesha, R., Satish K.B.P., Irfan, A.M. 2010. Antimicrobial activity of ethanol extract of leaf and flower of Spathodea campanulata P. Beauv. Research Journal of Pharmaceutical, Biological and Chemical Sciences (RJPBCS), 1: 691-698.

Ríos-Dueñas, E., Rodríguez-Avial, I., Picazo, J.J. 2011. In-vitro activity of ceftobiprole and seven other antimicrobial agents against invasive Streptococcus pneumoniae isolates in Spain. European Journal of Clinical Microbiology \& Infectious Diseases, 30: 1621-1625.

Sharifi-Rad, J., Hoseini-Alfatemi, S.M., Sharifi-Rad, M., Sharifi-Rad, M., Iriti, M., Sharifi-Rad, M., Sharifi-Rad, R., Raeisi, S. 2015. Phytochemical compositions and biological activities of essential oil from Xanthium strumarium L. Molecules, 20: 7034-7047.

Sharifi-Rad, J., Alfatemi, S.M.H., Sharifi-Rad, M. 2014a. In-vitro assessment of antibacterial activity of Salicornia herbacea L. seed extracts against multidrug resistant gram-positive and gram-negative bacteria. International Journal of Biosciences, 4: 217-222.

Sharifi-Rad, J., Hoseini-Alfatemi, S.M., Sharifi-Rad, M., Miri, A., Sharifi-Rad, M. 2014b. Phytochemical screening and antibacterial activity of Prosopis farcta different parts extracts against methicillinresistant Staphylococcus aureus (MRSA). Minerva Biotecnologica, 26: 287-293.

Sharifi-Rad, J., Alfatemi, S.M.H., Sharifi-Rad, M., Iriti, M. 2013. In-vitro antioxidant and antibacterial activities of Xanthium strumarium L. extracts on methicillin-susceptible and methicillin-resistant Staphylococcus aureus. Ancient Science of Life, 33: 107-111.

Trease, G.E., Evans, W.C. 1989. Pharmacognosy, 11 ${ }^{\text {th }}$ edition, Brailliar Tiridel Canada and UK, Macmillan Publisher, London, UK.

Uçar, G., Uçar, M.B. 2014. Geographical variation in the composition of Abies bornmuelleriana Mattf. needle oils. Records of Natural Products, 8: 5660 .

Vishnoi, S.P., Ghosh, A.K., Debnath, B., Samanta, S., Gayen, S., Jha, T. 2007. Antibacterial activity of Abies webbiana. Fitoterapia, 78: 153-155. 